\title{
De coronacrisis is een feministisch drama; hoe gaan we dit samen oplossen?
}

\author{
Yvonne La Grouw*
}

Onder het motto 'we doen dit met z'n allen' werden burgers het afgelopen jaar gemotiveerd om zich te voegen naar de coronamaatregelen. Terwijl 'we' met 'z'n allen' werken aan herstel, zijn de effecten van de coronacrisis niet voor iedereen hetzelfde. Structurele ongelijkheden zijn in de coronacrisis dieper ingesleten, met als opvallend dieptepunt de maatschappelijke positie van de vrouw. Vrouwen voeren veruit de meeste onbetaalde zorgtaken en thuisscholing uit (O’Reilly, 2020), vervullen het overgrote deel van de betaalde zorg- en onderwijsbanen (Bahn, Cohen \& Van der Meulen Rodgers, 2020), bevinden zich vaker in een precaire werk- en woonsituatie (Berkhout \& Richardson, 2020) en bovendien betekende de oproep om 'veilig thuis' te blijven meer huiselijk geweld jegens vrouwen (Kay, 2020). De combinatie van de grote vraag naar zorg, beperkende maatregelen en de daaruit volgende economische consequenties maken de pandemie een grote bedreiging voor de sociale positie, financiële zekerheid en arbeidszekerheid van vrouwen (Berkhout \& Richardson, 2020). De coronacrisis is een feministisch drama.

Deze uitkomst is niet zo vreemd wanneer de ingezette crisismanagementstrategieën onder de loep genomen worden. Deze strategieën kunnen gekenmerkt worden als typisch rationalistisch (Branicki, 2020). De keuzes in maatregelen zijn gebaseerd op een utilitaire logica gericht op kwantiteit en behoud, niet zozeer op kwaliteit of een toekomstvisie. Hierbij werd masculien en militair taalgebruik niet geschuwd - 'wij zijn sterker in de strijd tegen het virus'. De crisis wordt door middel van het benadrukken van meetbare cijfers en bronnen geschetst als een lineair proces van signaleren, voorbereiden, voorkomen, beheersing, herstel en leren (Branicki, 2020). Deze crisismanagementstrategieën doen reeds bestaande structurele ongelijkheden af als vervelend of jammer, maar niet als serieuze problemen die vragen om interventie. Zolang het herstelbeleid geen oog heeft voor het bestaan van deze structurele ongelijkheden, laat staan de versterkende negatieve effecten van het eigen beleid, zullen die paar vaders die nu vaker een boterham smeren voor hun kinderen geen deuk in een pakje boter slaan.

Een radicale verschuiving is nodig om los te komen van de rationalistische reflex van het crisisbeleid. De start van een nieuwe weg ligt in het erkennen en waarderen van de rol van zorg- en welzijnswerk. De coronacrisis legt bloot hoe onbetaald en betaald zorg- en welzijnswerk een integraal onderdeel is van een goed functio-

* Yvonne La Grouw MSc is PhD-candidate bestuurskunde en politicologie aan de Vrije Universiteit Amsterdam en redactielid van Beleid en Maatschappij. 
nerende samenleving én economie voor ons allen. Een focus op productie en economische groei doet af aan de waarde van dit werk en degenen die dat werk uitvoeren (Bahn e.a., 2020). Een uitweg kan mogelijk gevonden worden in zorgzaamheid als essentieel organiserend principe van de samenleving. Zorgzaamheid gaat om het vermogen om de politieke, sociale, materiële en emotionele omstandigheden te bieden die welzijn en bloei van mens, dier en omgeving mogelijk maken en onderhouden (Chatzidakis e.a., 2020). Loskomen van het versterken van structurele ongelijkheden vraagt om een collectieve verantwoordelijkheid voor zorgzaamheid. Dat zou zich vertalen naar maatregelen die een gezamenlijke verantwoordelijkheid en waardering voor onbetaalde en betaalde zorg normaliseren. Dit raakt een breed scala aan terreinen, van arbeidsomstandigheden tot onderwijs. Betere lonen en arbeidsvoorwaarden in zorg, welzijn en onderwijs; gelijke lonen voor vrouw en man; een kortere werkweek, zodat de zorg voor kinderen gemakkelijker verdeeld kan worden; gratis kinderopvang; uitgebreider en doorbetaald partner- en zwangerschapsverlof; een doeltreffendere aanpak van zwangerschapsdiscriminatie; kinderen leren dat zorgen een gedeelde taak is: het zouden zomaar wat eerste stappen kunnen zijn.

\section{Literatuur}

Bahn, K., Cohen, J., \& Meulen Rodgers, Y van der (2020). A Feminist Perspective on COVID-19 and the Value of Care Work Globally. Gender, Work \& Organization.

Berkhout, S.G., \& Richardson, L. (2020). Identity, politics, and the pandemic: Why is COVID-19 a disaster for feminism (s)? History and philosophy of the life sciences, 42 (4): 1-6.

Branicki, L.J. (2020). COVID-19, ethics of care and feminist crisis management. Gender, Work \& Organization, 27 (5): 872-883.

Chatzidakis, A., Hakim, J., Littler, J., Rottenberg, C., \& Segal, L. (2020). From carewashing to radical care: the discursive explosions of care during Covid-19. Feminist Media Studies, 20 (6): 889-895.

Kay, J.B. (2020). 'Stay the fuck at home!': feminism, family and the private home in a time of coronavirus. Feminist Media Studies, 1-6.

O’Reilly, A. (2020). 'Trying to Function in the Unfunctionable': Mothers and COVID-19. Journal of the Motherhood Initiative for Research and Community Involvement, 11 (1). 